\title{
Platelets: an unexploited data source in biomarker research
}

Citation for published version (APA):

Sabrkhany, S., Kuijpers, M. J. E., Verheul, H. M. W., Griffioen, A. W., \& Egbrink, M. G. A. O. (2015).

Platelets: an unexploited data source in biomarker research. The Lancet Haematology, 2(12), E512-E513. https://doi.org/10.1016/S2352-3026(15)00225-2

Document status and date:

Published: 01/12/2015

DOI:

10.1016/S2352-3026(15)00225-2

Document Version:

Publisher's PDF, also known as Version of record

Document license:

Taverne

Please check the document version of this publication:

- A submitted manuscript is the version of the article upon submission and before peer-review. There can be important differences between the submitted version and the official published version of record.

People interested in the research are advised to contact the author for the final version of the publication, or visit the DOI to the publisher's website.

- The final author version and the galley proof are versions of the publication after peer review.

- The final published version features the final layout of the paper including the volume, issue and page numbers.

Link to publication

\footnotetext{
General rights rights.

- You may freely distribute the URL identifying the publication in the public portal. please follow below link for the End User Agreement:

www.umlib.nl/taverne-license

Take down policy

If you believe that this document breaches copyright please contact us at:

repository@maastrichtuniversity.nl

providing details and we will investigate your claim.
}

Copyright and moral rights for the publications made accessible in the public portal are retained by the authors and/or other copyright owners and it is a condition of accessing publications that users recognise and abide by the legal requirements associated with these

- Users may download and print one copy of any publication from the public portal for the purpose of private study or research.

- You may not further distribute the material or use it for any profit-making activity or commercial gain

If the publication is distributed under the terms of Article $25 \mathrm{fa}$ of the Dutch Copyright Act, indicated by the "Taverne" license above, 


\section{Platelets: an unexploited data source in biomarker research}

Biomarker assessment from blood samples is frequently based on measurements in serum or plasma. By doing so, the biomarker content of blood cells is neglected. The potential importance of platelets in such studies is exemplified by knowledge obtained from recent studies on cancer. Circulating platelets contain vast amounts of bioactive proteins in their granules, such as growth factors, chemokines, cytokines, and proteases, which they can secrete on activation. ${ }^{1}$ These proteins are either synthesised or taken up by the megakaryocytes that produce the platelets, or selectively absorbed from the blood by the circulating platelets themselves. ${ }^{2,3} \mathrm{As}$ a result, the concentration of these potential biomarkers is much higher inside platelets than in plasma. ${ }^{2.4}$ In addition, platelets from-for example-patients with cancer might have a higher growth factor content than do platelets from healthy controls. ${ }^{5}$ Animal studies have shown that platelets are able to sequester angiogenesis regulatory proteins secreted from clinically undetectable tumours (measuring $<1 \mathrm{~mm}^{3}$ ), resulting in higher concentrations of these proteins in platelets without significant changes in plasma concentrations. ${ }^{2}$ In diseases other than cancer, platelet characteristics and content are also potentially interesting biomarkers. ${ }^{6}$ Therefore, use of measurements exclusively from plasma or serum may not be sufficient for the understanding of underlying biological processes and could obscure the presence of biomarkers.

The functional relevance of inclusion of platelet content in the search for blood-based biomarkers in cancer research is shown by the fact that platelets can support and stimulate tumour angiogenesis and growth. ${ }^{1}$ They release their $\alpha$-granule content into the blood when they adhere to tumour endothelium and become activated, resulting in a local increase in concentration of pro-angiogenic and anti-angiogenic regulatory proteins inside the tumour. The net effect of this mix of stimulatory and inhibitory proteins is an increase in angiogenesis and, hence, tumour growth. ${ }^{1}$ Beside endocytosis of angiogenesis regulators, platelets also take up intravenously administered anti-angiogenic medication, as shown for the monoclonal antibody bevacizumab. Within the $\alpha$-granules, this antibody neutralises VEGF, which results in reduced platelet angiogenic activity.
Pretreatment thrombocytosis is an independent predictor of poor prognosis in various types of malignancies such as lung, breast, colorectal, renal cell, and ovarian cancer. ${ }^{7}$ The fact that altered platelet count is frequently detected in patients with malignancy emphasises the potential importance of platelets in cancer biomarker research. In addition, high serum VEGF concentrations in patients with cancer are correlated with platelet count. ${ }^{8}$ The question whether high serum VEGF concentrations are an indication of tumour burden or merely a reflection of platelet count shows the potential confusion when platelet content is ignored in biomarker research.

Notably, platelets are susceptible to manipulations and can easily become activated during blood collection and processing. Therefore, when biomarkers are measured using stored platelets, the use of proper anticoagulant and blood collection and processing techniques is imperative to prevent platelet activation and secretion. ${ }^{9}$ However, even when all the appropriate precautions have been taken into account, the number of platelets can still affect growth factor concentration in serum or plasma. ${ }^{10}$ In addition, in patients with cancer local and systemic platelet activation might occur in vivo, potentially resulting in growth factor release into the circulation. ${ }^{1}$ Hence, measurement of growth factor concentrations in only serum or plasma can cause investigators to overlook the role of platelets and their growth factor content.

Therefore, we suggest that platelet-derived growth factors, chemokines, and cytokines should be measured in both plasma and platelets. These measurements should not be done in serum, because some or most of the content of the $\alpha$-granules from platelets will be released during clotting.

Thus far, promising results have been shown in different mouse models in which platelet angiogenic content has been measured in the presence and absence of different types of (human) tumours. Concentrations of various pro-angiogenic growth factors such as VEGF, basic fibroblast growth factor (bFGR), and platelet-derived growth factor (PDGF) were higher in platelets of tumour-bearing mice than in non-tumour bearing controls. By contrast, the plasma concentrations of these proteins did 
not change in the presence of a growing tumour. ${ }^{2}$ Furthermore, platelet-derived anti-angiogenic factors might represent potential biomarkers of tumour growth. Thrombospondin-1 (TSP-1) and platelet factor 4 (PF-4), potent angiogenesis inhibitors, were increased in platelets of tumour-bearing mice. Again, TSP-1 and PF-4 concentrations were not increased in plasma. ${ }^{3,10}$ The increase in TSP-1 in platelets seemed to be solely due to increased TSP-1 packaging by megakaryocytes in the presence of a tumour. ${ }^{3}$

Clinical studies of the biomarker content of platelets are scarce. Platelet content was assessed in two studies in human beings. ${ }^{4,5}$ In the first study, ${ }^{4}$ blood was collected from 50 healthy individuals at single and repetitive timepoints to determine the normal concentrations of VEGF, bFGR, PDGF, TSP-1, endostatin, and PF-4. As expected, the concentrations of these angiogenesis regulatory proteins were much higher in platelets than in platelet-poor plasma. The biovariability of these proteins over a 5 -week period was minimal. In the second study, ${ }^{5}$ growth factor levels in platelets and platelet poor plasma were assessed in 35 patients with colorectal cancer. Concentrations of VEGF, PDGF, and PF-4 were higher in platelets of patients with cancer than in platelets from healthy individuals. Furthermore, the increase in angiogenesis regulatory proteins correlated with cancer stage. VEGF, PDGF, and PF-4 expression discriminated between patients with cancer and healthy controls (area under the curve $0.893,95 \% \mathrm{Cl} 0.844-0.955 ; \mathrm{p}<0.0001)$. At the same time, concentrations of angiogenic factors in plasma did not differ between groups. Beside this potential role as biomarker source for tumour growth and cancer stage, platelets might also function as important carriers of information during the monitoring of residual disease after therapeutic interventions.

In conclusion, we advise clinicians and researchers to look beyond traditional fluid sources such as plasma or serum in their search for biomarkers. Until now platelets have been a relatively unexploited source of information, not only in patients with cancer but also in, for example, cardiovascular and neurodegenerative diseases. We recommend platelet counts as well as their content should be taken into account. Such an extended analysis of the whole blood content might increase the chances for breakthroughs in biomarker research.

Siamack Sabrkhany, Marijke J E Kuijpers, Henk M W Verheul, Arjan W Griffioen, *Mirjam G A oude Egbrink

Cardiovascular Research Institute Maastricht, Department of Physiology (SS, MGAoE) and Department of Biochemistry (MJEK) Maastricht University, PO Box 616, 6200 MD Maastricht Netherlands; and Angiogenesis Laboratory, Department of Medical Oncology, VU University Medical Center, PO Box 7057, 1007 MB, Amsterdam, Netherlands (HMWV, AWG) m.oudeegbrink@maastrichtuniversity.nl

This work is financially supported by the Netherlands Organization for Scientific Research (NWO) under project number 017.008.143, granted to SS. We declare no competing interests.

1 Sabrkhany S, Griffioen AW, oude Egbrink MG. The role of blood platelets in tumor angiogenesis. Biochim Biophys Acta 2011; 1815: 189-96.

2 Klement GL, Yip TT, Cassiola F, et al. Platelets actively sequester angiogenesis regulators. Blood 2009; 113: 2835-42.

3 Zaslavsky A, Baek KH, Lynch RC, et al. Platelet-derived thrombospondin-1 is a critical negative regulator and potential biomarker of angiogenesis. Blood 2010; 115: 4605-13.

4 Peterson JE, Zurakowski D, Italiano JE, et al. Normal ranges of angiogenesis regulatory proteins in human platelets. Am J Hematol 2010; 85: 487-93.

5 Peterson JE, Zurakowski D, Italiano JE, et al. VEGF, PF4 and PDGF are elevated in platelets of colorectal cancer patients. Angiogenesis 2012; 15: $265-73$.

6 Kamath S, Blann AD, Caine GJ, et al. Platelet P-selectin levels in relation to plasma soluble P-selectin and beta-thromboglobulin levels in atrial fibrillation. Stroke 2002; 33: 1237-42.

7 Lin RJ, Afshar-Kharghan V, Schafer Al. Paraneoplastic thrombocytosis: the secrets of tumor self-promotion. Blood 2014; 124: 184-87.

8 George ML, Eccles SA, Tutton MG, Abulafi AM, Swift RI. Correlation of plasma and serum vascular endothelial growth factor levels with platelet count in colorectal cancer: clinical evidence of platelet scavenging? Clin Cancer Res 2000; 6: 3147-52.

9 Sabrkhany S, Kuijpers MJE, Verheul HMW, oude Egbrink MGA, Griffioen AW. Optimal human blood sampling for platelet research. Current Angiogenesis 2014; 2 : 157-61

10 Cervi D, Yip TT, Bhattacharya N, et al. Platelet-associated PF-4 as a biomarker of early tumor growth. Blood 2008; 111: 1201-07. 